University of South Carolina

Scholar Commons

$1-1-2005$

\title{
Flexible Multiobjective Control of Power Converter in Active Hybrid Fuel Cell/Battery Power Sources
}

Zhenhua Jiang

University of Miami, zjiang1@miami.edu

Lijun Gao

Boeing, Lijun.gao@boeing.com

Roger A. Dougal

University of South Carolina - Columbia, dougal@engr.sc.edu

Follow this and additional works at: https://scholarcommons.sc.edu/elct_facpub

Part of the Electrical and Computer Engineering Commons

Publication Info

Published in IEEE Transactions on Power Electronics, Volume 20, 2005, pages 244-253.

http://ieeexplore.ieee.org/xpl/Recentlssue.jsp?punumber=63

(C) 2005 by IEEE

This Article is brought to you by the Electrical Engineering, Department of at Scholar Commons. It has been accepted for inclusion in Faculty Publications by an authorized administrator of Scholar Commons. For more information, please contact digres@mailbox.sc.edu. 


\title{
Flexible Multiobjective Control of Power Converter in Active Hybrid Fuel Cell/Battery Power Sources
}

\author{
Zhenhua Jiang, Member, IEEE, Lijun Gao, Member, IEEE, and Roger A. Dougal, Senior Member, IEEE
}

\begin{abstract}
Hybrid power sources composed of fuel cells and secondary batteries can combine the high energy density of fuel cells with the high power density of batteries. A dc/dc power converter can be placed between the fuel cell and the battery to balance the power flow and greatly augment the peak output power. This paper presents a novel, flexible strategy for multiobjective control of the power converter in the hybrid power source. The control strategy is able to regulate the output current of the fuel cell and the charging current or voltage of the battery while limiting the discharging current of the battery. It can be used in two different configurations without any change. The control strategy is implemented in MATLAB/Simulink and tested by simulation and experiments. Simulation and experimental results show that the multiobjective control strategy is able to select the regulation mode correctly and the fuel cell current, battery current and battery voltage are regulated appropriately. Experiment results demonstrate the great flexibility and generality of the control strategy and validate that the peak power capacity of the active hybrid power source is increased significantly. Simulation and experiment results also show that power converter can be appropriately regulated to meet the multiple objectives required by hybrid power sources.
\end{abstract}

Index Terms-Battery, fuel cell, hybrid power source, multiobjective control, power converter.

\section{INTRODUCTION}

$\mathbf{N}$ EW high-energy density, high-power density power sources are more and more attractive to applications of modern handheld electronic devices and larger machines such as electric vehicles or aircraft on both commercial and military markets [1], [2]. In most cases, current technology batteries by themselves are insufficient to provide the long-term power (energy between refuelings) that these systems require. Many applications such as computers (disk drives), radios, cellular phones, etc, have a common characteristic in the load profile, i.e., they have a relatively low average power requirement but occasional or periodic demands for higher power. Fuel cells of reasonable size may provide the necessary energy, but not the peak power demanded by these systems. Hybrid systems composed of fuel cells and batteries combine the high energy density of fuel cells with the high power density of batteries [3]-[6] in order to meet both of these requirements. Furthermore, a fuel cell/battery hybrid system could have a number of advantages over each component. Provided that the temperature was not too cold, the battery could enable instant cold-start operation since it can provide a majority of

Manuscript received December 9, 2003; revised July 14, 2004. This work was supported by the U.S. Office of Naval Research under Contract N00014-03-10952. Recommended by Associate Editor K. Ngo.

The authors are with the Department of Electrical Engineering, University of South Carolina, Columbia, SC 29208 USA.

Digital Object Identifier 10.1109/TPEL.2004.839782

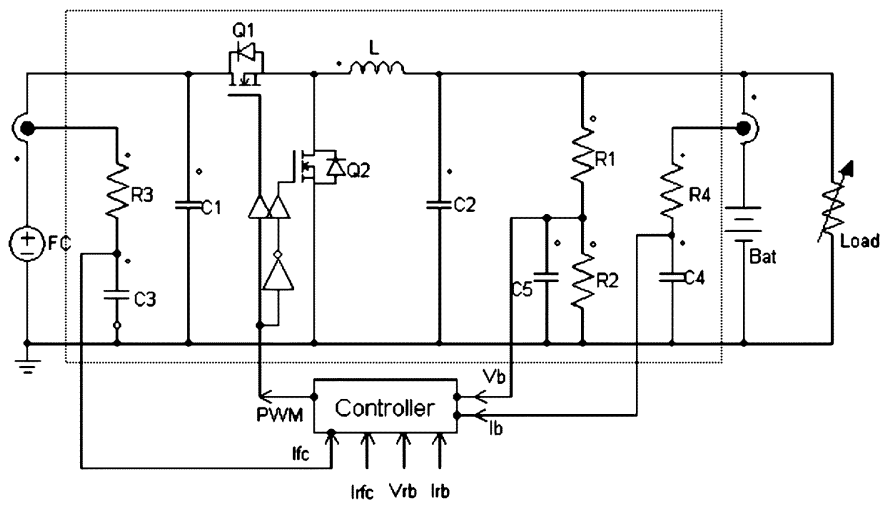

Fig. 1. Circuit diagram of the active hybrid fuel cell/battery power source (Configuration I).

the load power requirement while the fuel cell is warming up. A hybrid system could allow both components to be of smaller dimensions and to operate with higher efficiency since neither would have to provide full load and capacity. The battery could also condition the power output from the fuel cell to provide a voltage range that is acceptable to the equipment since battery operated devices are generally designed to accommodate the source characteristics of a battery (i.e., voltage fluctuation from full charge to depleted).

The simplest hybrid configuration results by connecting both the fuel cell and the battery directly to the power bus [6]. This passive hybrid has a number of disadvantages. First, because the power is passively distributed between the fuel cell and the battery, depending on the characteristics of each component, the maximum output current of the hybrid system might be limited by the current capacity of the fuel cell. Second, it is necessary to match the nominal voltage of the fuel cell stack to that of the battery, which eliminates much flexibility in the system design. As an alternative to the passive hybrid, a dc/dc power converter could be placed between the fuel cell and the battery [7], which would greatly augment the peak output power while reducing the system weight and volume. The active fuel cell/battery/converter hybrids could be configured in two different ways, as will be shown later in Figs. 1 and 2, depending on the position of each component. In both configurations, the power shared by both components could then be actively controlled. However, control of the power converter in such systems becomes very complicated, which actually is a multiobjective control issue [8], [9]. Rather than being controlled to serve as a sole voltage or current regulator, the power converter is required to balance the power flow between the fuel cell and the battery to satisfy the load power requirements while ensuring the operation within any limitations of the electrochemical components such as battery over-charge/over-discharge, fuel cell current limit, etc. 


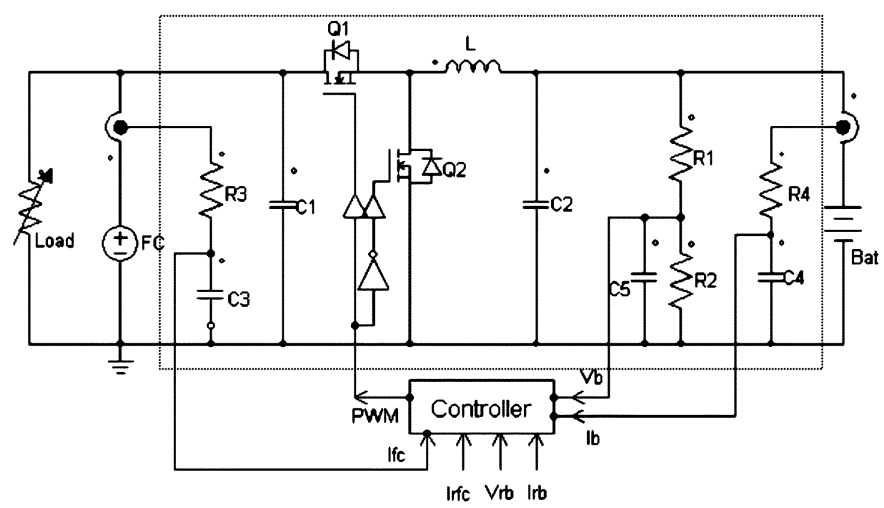

Fig. 2. Circuit diagram of the active hybrid fuel cell/battery power source (Configuration II).

TABLE I

PARAMETERS OF THE POWER CONVERTER

\begin{tabular}{c|c}
\hline Component/Parameter & Description \\
\hline MOSFETs & IRF530 \\
\hline MOSFET driver & IR2184 \\
\hline Current sensors & LEM HAW03-P \\
\hline Power inductor & $470 \mathrm{uH}$ \\
\hline Input/output capacitors & $110 \mathrm{uF}$ \\
\hline
\end{tabular}

This paper presents a new, flexible strategy for multiobjective control of the power converter in active hybrid fuel cell/battery power sources. This control strategy can be used for two different configurations without any change. The remainder of this paper is organized as follows. Two configurations of hybrid power sources are discussed in Section II. Section III describes the flexible multiobjective control strategy for the power converter in the hybrid power sources and the Simulink implementation of the control strategy. The proposed state machine model of multiobjective control strategy can be used in other kinds of hybrid power sources. The simulation results are given in Section IV. Section V presents the experiment results. Simulation and experiment results show that the control strategy is able to select the regulation mode correctly and the fuel cell current, battery current and battery voltage can be regulated appropriately. Experiment results validate the flexibility and generality of the control strategy and demonstrate the significantly increased capability of peak output power with the addition of a power converter in the hybrid power source. Conclusions are made in Section VI.

\section{Configurations of Active Hybrid Power Sources}

In the active fuel cell/battery/converter hybrids, the positions of the fuel cell and the battery determine the terminal voltage and power characteristics of hybrid power sources. Two possible configurations of active hybrid fuel cell/battery power sources are briefly discussed here.

Fig. 1 schematically shows the circuit diagram of one configuration of hybrid power sources (Configuration I). In this system, the load is directly connected to the battery while the fuel cell is connected to both the load and the battery through a synchronous buck converter. A voltage chopper consisting of a main switch $Q_{1}$ and a secondary switch $Q_{2}$ (operating as a synchronous rectifier) converts the voltage from the fuelcell stack to an appropriate lower voltage so that a smaller number of battery cells are needed than using a step-up dc/dc converter (the terminal voltage of the battery equals to the summation of the voltages of all the cells in series). The synchronous rectifier is chosen (instead of a junction diode), which is now a standard configuration in low-voltage systems [10], because the voltage-drop of the metal oxide semiconductor field effect transistor (MOSFET) switch as synchronous rectifier is about $0.1 \mathrm{~V}$, better than a junction diode (about $0.6 \mathrm{~V}$ ) by a factor of 6. The lower voltage-drop of the synchronous MOSFET translates into higher system efficiency. The power inductor $\mathrm{L}$ filters the ripple in the output current. The capacitor $C_{1}$ filters the input, whilecapacitor $C_{2}$ smoothes the ripplein the output voltage The battery provides additional power when the load needs high peak power and is charged by the fuel cell when the load is low. Power flows unidirectionally through the synchronous buck converter (from the fuel cell side to the battery side). The voltage of theloadfollows the battery voltage (lowervoltage level). Although the bus is floating at the battery voltage, controlling the power converter can change the output current of the fuel cell and thus the current (and voltage) supplied by the battery. Two current sensors are used to measure the currents from the fuel cell and to the battery respectively. Resistors $R_{1}$ and $R_{2}$ form a voltage divider to measure the battery voltage. The measured signals are filtered with single-pole low-pass filters having cutoffs at around $1 \mathrm{kHz}$. Table I describes the major parameters of the power converter.

Connecting the load to the fuel cell (rather than to the battery) results in another configuration of hybrid power sources (Configuration II) that is shown in Fig. 2. In this system, the fuel cell is directly connected to the load while the battery is charged or discharged through the power converter that now acts as a bi-directional dc/dc converter (as a boost converter when the battery is discharged). Power flows through the $\mathrm{dc} / \mathrm{dc}$ converter in both directions. The bus voltage follows the fuel cell voltage (higher voltage level). Although the power bus is floating at the fuel cell terminal voltage, controlling the power converter can change the charging/discharging current of the battery and thus the current (and voltage) of the fuel cell.

In both configurations, the measured fuel cell current, battery voltage and battery current are fed into the controller. Their reference values are set by $I_{\mathrm{rfc}}, V_{\mathrm{rb}}$, and $I_{\mathrm{rb}}$, respectively. The controller calculates the duty cycle and produces a continuous PWM signal to the buck converter. Proper configuration of hybrid power sources can be chosen for a specific application according to load voltage requirements or power characteristics [7]. In the following, a strategy will be described that is suitable for these two configurations and is able to regulate the output current of the fuel cell and the charging current or voltage of the battery.

\section{Multiobjective Control Strategy of Power CONVERTER}

In either hybrid system configuration, the only control input is the duty cycle of the power converter. By changing the duty cycle, the output current of the fuel cell and the current (or voltage) of the battery can be regulated, but not independently. The control strategy that we describe here has three regulation modes in both configurations: constant fuel cell current 
(CFCC) mode, constant battery current (CBC) mode, and constant battery voltage (CBV) mode. In either system configuration, the battery voltage is an important index of the regulation mode. If the battery voltage exceeds the reference voltage, which may correspond to the condition of no load or a light load coupled with high battery charge level, constant battery voltage (CBV) mode applies. Under this mode, the output current of the fuel cell and the charging current of the battery should be below the rated currents. If the battery voltage is below the reference voltage, which may correspond to the condition of a heavy load or a light load coupled with low battery charge level, constant fuel cell current (CFCC) mode or constant battery current (CBC) mode may apply, depending on the load. If the load demand makes the fuel cell current lower than the rated output current, the charging current of the battery may need to be regulated in order to protect the battery, i.e., constant battery current (CBC) mode applies. In this case, the fuel cell current is unregulated but is always below the rated current. If the load demand is very high, the fuel cell current may reach the limit and then constant fuel cell current (CFCC) mode may apply. In this case, the battery may be discharged or charged at a lower rate.

Fig. 3 shows the state machine representation [11] of the control strategy described above. The circles represent the regulation modes (states) of the system. The arrows indicate changes from one regulation mode to another (events). Each event happens under a corresponding condition that is unique to the current regulation mode (state). When the power source is first turned on, it initially always works in CFCC mode. If there is no load or a light load, the charging current of the battery may increase quickly from zero to the limit current, and then CBC mode applies. Whenever the battery voltage reaches the reference voltage, $\mathrm{CBV}$ mode will apply. Under either CBC mode or CBV mode, if the load increases very quickly (i.e., when the fuel cell current reaches the limit), CFCC mode will apply. Under any of these three modes, the load will be disconnected (DISC) if the battery discharging current exceeds the safe operating limit (for instance, four times the rated charging current), which corresponds to the condition that the load is extremely heavy.

At any time, the control strategy selects only one regulation mode and then the power converter has only one control objective. The duty cycle of the power converter is then set according to this objective. Whenever a change in the fuel cell, the battery or the load results in satisfaction of the corresponding event condition, the control strategy will move to another regulation mode and the control output (the duty cycle of the power converter) is calculated afresh according to the new objective, which makes it possible to implement the multiobjective control strategy with only a single control variable. In the configurations shown in Figs. 1 and 2, this control strategy accounts for all of the possible regulation modes and the corresponding conditions that result in the changes of regulation modes. Under any condition of the load, the control strategy can select the regulation mode appropriately, as will be shown later in this paper. In other words, the described control strategy is able to regulate the fuel cell current, the charging current or voltage of the battery while limiting the discharging current of the battery.

MATLAB/Simulink is selected as the tool for the control system design for two reasons. First, an interface to Simulink

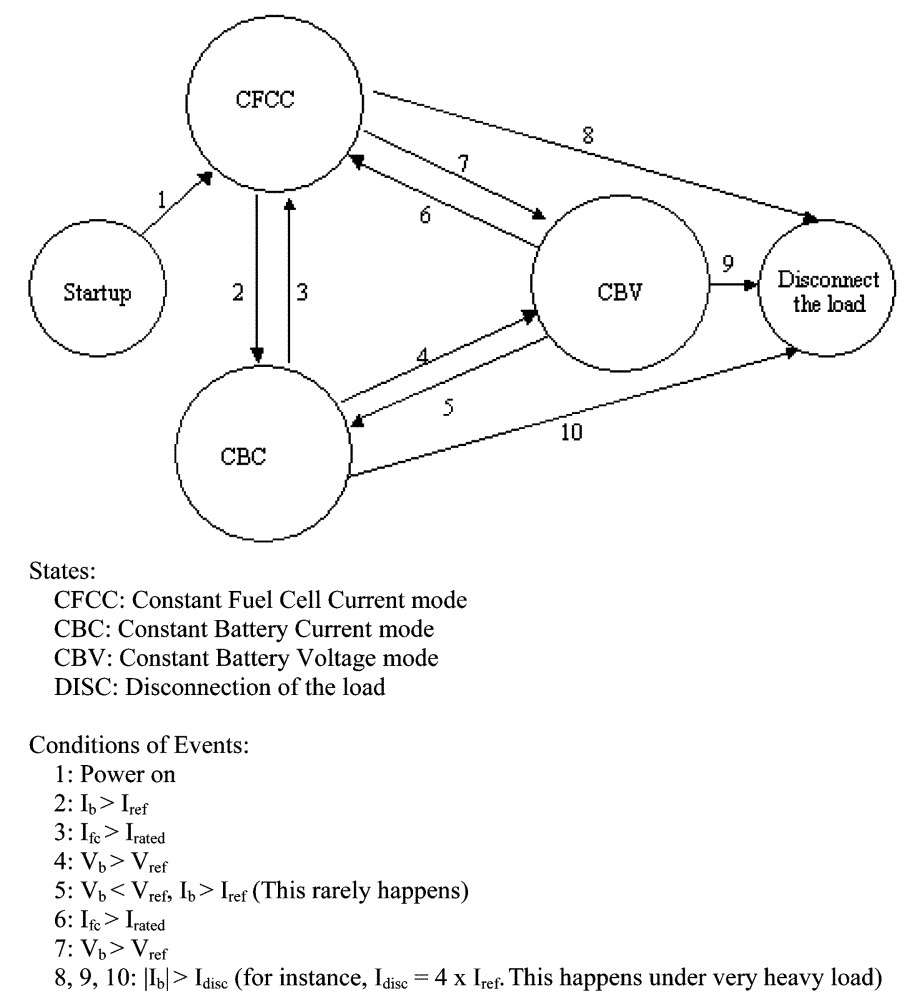

Fig. 3. State machine representation of the control strategy for active hybrid fuel cell/battery power sources.

is available in the virtual test bed (VTB), which is a multidisciplinary simulation environment for complex dynamic systems [12]. Using both pieces of software makes it possible to test the control algorithm with very detailed models of all of the hardware components, including fuel cell, battery and power electronics. Secondly, the MATLAB software provides an interface layer to a general-purpose digital controller (here, dSPACE DS1103) [13] which is used here only for rapid control prototyping and experimental validation of the strategy. The final product would instead contain a dedicated microcontroller.

Fig. 4 shows the Simulink implementation of the control strategy. This Simulink model has three input variables-fuel cell current, battery current, and battery voltage, and two output variables-duty cycle of the power converter and enabling signal that can disconnect the load from the power source whenever the battery is over-discharged. The main functional blocks in this Simulink model are the regulation mode select module and the compensation loop module. The regulation mode select module realizes the control strategy shown in Fig. 3 and outputs the regulation mode selected. The regulation mode is determined according to the current operating conditions (the previous regulation mode and the measured currents and voltages) and the logic of the control strategy. The compensation loop module is used to compute the duty cycle of the power converter according to the selected regulation mode (control objective). A modified proportional-integral (PI) approach is used to regulate the currents and voltages. The controller has different compensation objectives when different regulation modes are selected. In order to reduce the voltage or current transients that may occur when the regulation mode is changed, the control scheme consists of a feed-forward term 


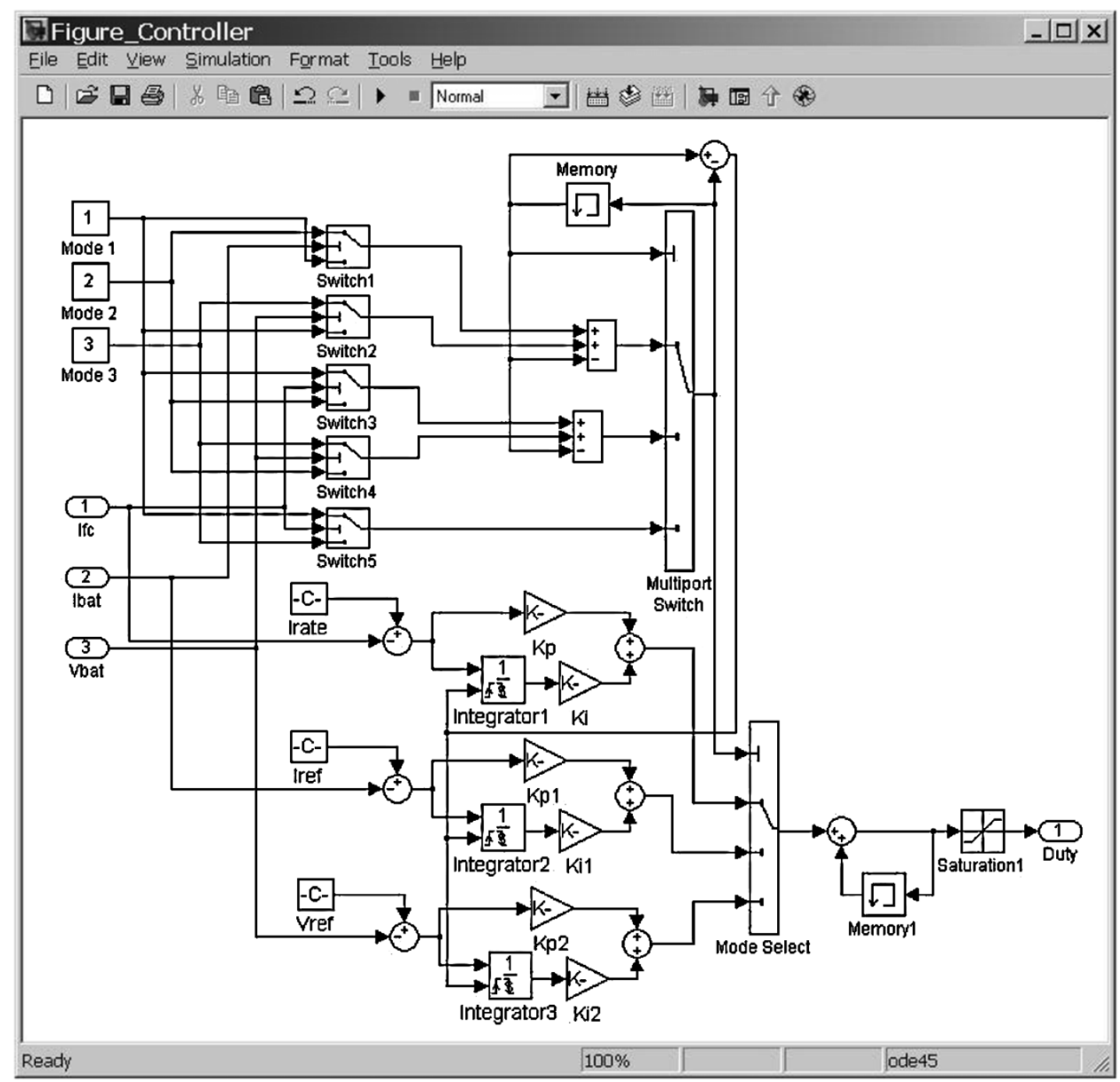

Fig. 4. Simulink implementation of the multiobjective control strategy.

(implemented by the duty cycle at the previous sample interval) plus the proportional and integral terms of the errors of the currents or voltage [14]. The duty cycle at the previous sample interval was stored in a memory for calculation of the duty cycle at the current step. The proportional and integral terms of the errors are actually compensating the change of the duty cycle $(\Delta d)$ at the current step. By doing these, the duty cycle will not change a lot at the time of mode change, and both the fuel cell current and the battery current can be regulated within the limits, even if the transitions 2 and 3 may potentially be oscillatory when $I_{\text {ref }}$ and $I_{\text {rated }}$ are not selected appropriately or if the load varies frequently, because the effect of the fuel cell current error on the change of the duty cycle is similar to that of the charging current error. Whenever the regulation mode is changed, each integrator is reset to avoid unusual current or voltage transients at the time of mode change. The current and voltage regulations are formulated in

$$
\begin{aligned}
d & =d_{\text {old }}+k_{\text {pifc }}\left(I_{\text {rated }}-I_{\mathrm{fc}}\right) / I_{\text {rated }} \\
& +k_{\text {iifc }} \int\left(I_{\text {rated }}-I_{\mathrm{fc}}\right) / I_{\text {rated }} d t \\
d & =d_{\text {old }}+k_{\text {pi }}\left(I_{\text {ref }}-I\right) / I_{\text {ref }}+k_{\text {ii }} \int\left(I_{\text {ref }}-I\right) / I_{\text {ref }} d t
\end{aligned}
$$

$$
d=d_{\text {old }}+k_{\mathrm{pv}}\left(V_{\text {ref }}-V\right) / V_{\text {ref }}+k_{\mathrm{iv}} \int\left(V_{\text {ref }}-V\right) / V_{\text {ref }} d t
$$

where $I_{\mathrm{fc}}$ is the sampled current from the fuel cell stack, $V$ is the sampled voltage of the battery, $I$ is the sampled current to the battery, $d$ is the duty cycles used to control the buck converter, $d_{\text {old }}$ is the value of the duty cycle left off the last time when the particular mode was engaged, $I_{\text {rated }}, V_{\text {ref }}$, and $I_{\text {ref }}$ are the reference fuel cell current, reference battery voltage and reference battery charging current, respectively, $k_{\mathrm{pifc}}, k_{\mathrm{iifc}}, k_{\mathrm{pi}}, k_{\mathrm{ii}}$, and $k_{\mathrm{pv}}, k_{\mathrm{iv}}$ are proportional and integral gains for the fuel cell current, battery current, and battery voltage, respectively. Since the modified PI control scheme contains the duty cycle value left off the last time, the proportional term of the error may compensate the control in a way similar to the integral term in a traditional PI algorithm, and the integral gain in the modified PI algorithm does not necessarily have a large value, as does that in a traditional PI algorithm.

\section{Simulation Studies AND Results}

In order to investigate the performances of the multiobjective control strategy, simulation studies are first conducted in the VTB, 


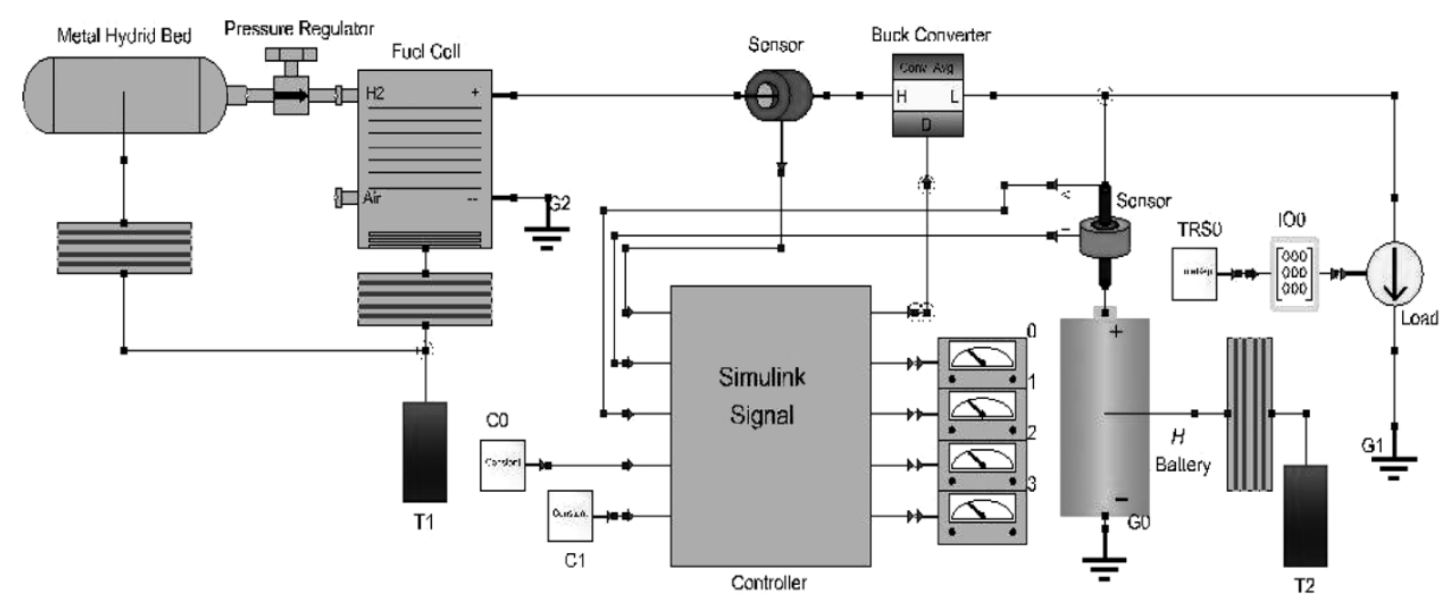

Fig. 5. VTB schematic view of the active hybrid fuel cell/battery power source.

which is endowed with mechanisms for importing models from MATLAB and co-simulating with Simulink. Configuration I of the active hybrid power source is studied here as an example. It is worthwhile to note that the same simulation was done for Configuration II, but is not described in detail here. Fig. 5 shows the VTB schematic view of the hybrid system shown in Fig. 1 (Configuration I). A 25-cell PEM fuel cell stack is the primary power source. The PEM fuel cell model considers the nonlinear electrical characteristics on the electrodes, hydrogen flow, and heat produced [15], [16]. A metal hydride bed [16] is connected to the fuel cell through a pressure regulator to supply hydrogen at $1.0 \mathrm{~atm}$ $\left(1.0133 \times 10^{5} \mathrm{~Pa}\right)$ constant pressure. Air is also fed to the fuel cell at $1.0 \mathrm{~atm}$ constant pressure. Both the fuel cell and the metal hydride bed are configured to independently exchange heat with the ambient environment (i.e., the temperature source). As the secondary power source, a battery provides additional power when the load needs peak power and is charged by the fuel cell when the load is low. The battery is configured as four cells in series and two strings in parallel. The capacity of each cell is $1.4 \mathrm{Ah}$. The initial state-of-charge of the battery is 0.88 . The battery also exchanges heat with the ambient environment. The battery model represents the electrical properties of the battery by a second-order circuit of resistor-capacitor combination in series with a nonlinear voltage source that depends on state of charge and is validated against experiment data [17]. The load draws a pulse current of period of 30 $\mathrm{s}$. The low current is $0.3 \mathrm{~A}$ for $27 \mathrm{~s}$ and the high current is $9 \mathrm{~A}$ for $3 \mathrm{~s}$. The power converter is represented by a switching-average bi-directional dc/dc converter model. Since the PWM signal controls the high-side switch of the converter, the input/output voltage relationship of the converter is $V_{\mathrm{H}}=V_{L} / d$ where $V_{H}$ and $V_{L}$ are, respectively, average voltages on the high side and low side of the converter and $d$ is the duty cycle of the PWM signal driving the high-side switch. The power converter model also represents the conduction loss by considering $120 \mathrm{~m} \Omega$ on-resistance of the switch.

The Simulink model of the controller that is shown in Fig. 4 is embedded into the VTB simulation. The limit of the fuel cell current is set at $2.2 \mathrm{~A}$. The reference charging current of the battery is set to $1.8 \mathrm{~A}$, according to the maximum safe charging rate of the battery. The maximum voltage of the battery is set to 16.6 V. The gains of PI compensation could be mathematically

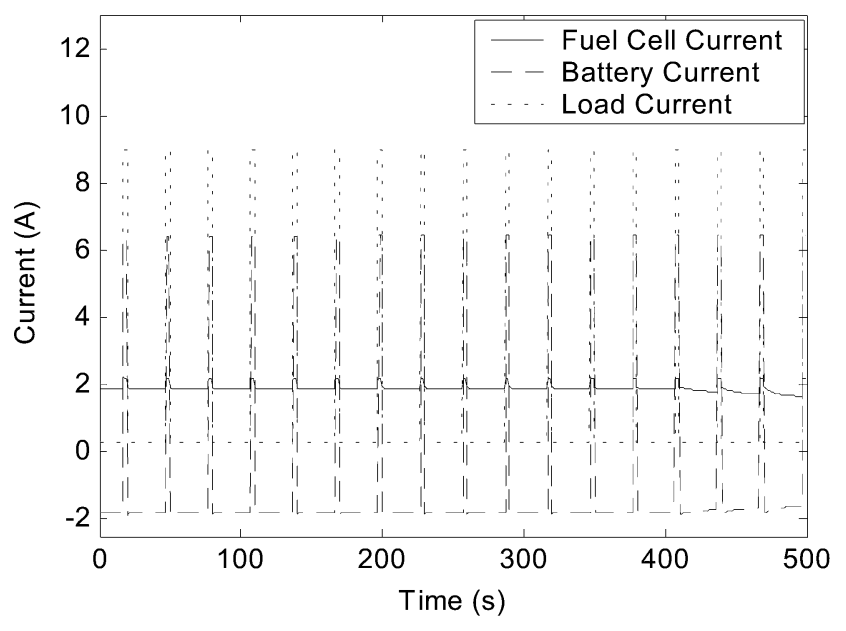

Fig. 6. Currents from the fuel cell stack, from the battery, and to the load.

found by specifying the bandwidth and phase margin requirements of the loop gain or by placing the corresponding poles or zeros for the closed-loop system. Since the system transfer function is difficult to obtain and subject to change, the gains for both current and voltage regulations are manually tuned by observing the system performances, under the condition of ensuring the system stability under two configurations. Table II shows the gains for current and voltage regulations used in the control algorithm. The simulation is run for $500 \mathrm{~s}$, and the simulation results are shown in Figs. 6-10. Fig. 6 shows the currents from the fuel cell stack, from the battery and to the load, which initially vary periodically and begin to look different after $400 \mathrm{~s}$. Some details of these currents are shown in Fig. 10. Fig. 7 shows the voltages of the fuel cell stack and the battery. Note that the voltage of the load is equal to the voltage at the battery terminals. The state-of-charge of the battery as computed inside its model is plotted in Fig. 8. Fig. 9 displays the changes of regulation modes.

During each of the first cycles, it is shown in Figs. 6 and 10 that when the load draws a low current $(0.3 \mathrm{~A})$ the fuel cell provides about $1.7 \mathrm{~A}$ current (lower than the limit current) and the battery is charged at $1.8 \mathrm{~A}$ reference current. At this moment, CBC mode applies (see Fig. 9). These currents do not 


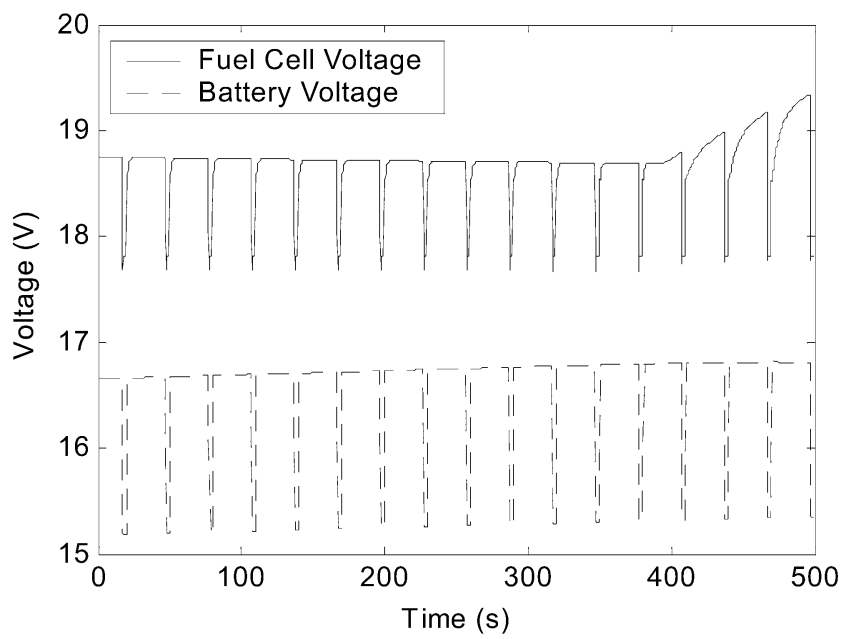

Fig. 7. Voltages of the fuel cell and the battery (the voltage of the load equals to the battery voltage).

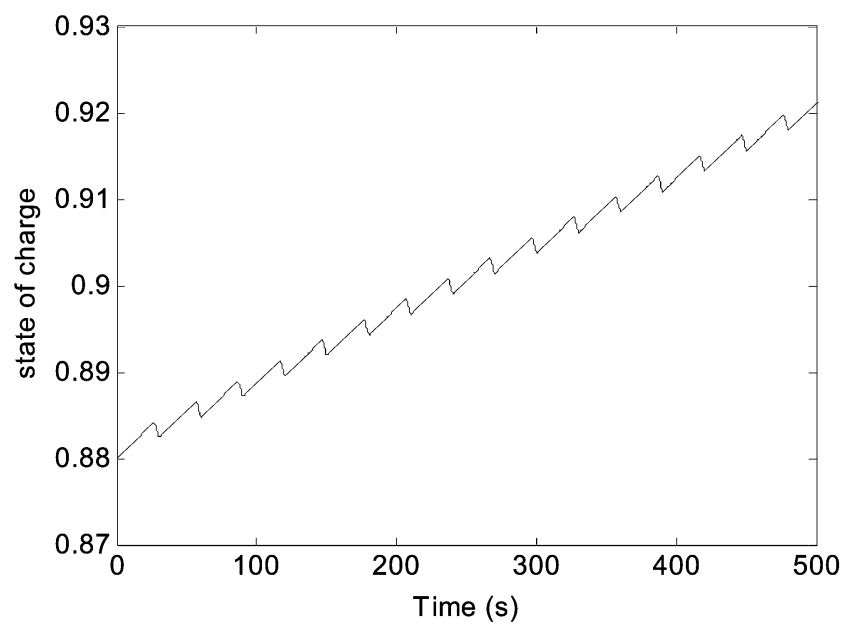

Fig. 8. Calculated state-of-charge of the battery.

sum to zero because the voltages are different at the input and output of the power converter. It is seen from Fig. 7 that the battery voltage increased gradually when the load current is low. When the load draws peak power, the fuel cell supplies 2.2 A current (the current limit) and the terminal voltage of the fuel cell drops suddenly. Although the fuel cell model does not account for transient hydration effects, still it accurately enough represents the real hardware, as will be shown in the experiments. At this time, the battery discharged at approximately 6.5 A current, depending on the load, and the voltage dropped suddenly and then decreased gradually. In this case, CFCC mode applies (see Fig. 9). During some cycle when the battery voltage reaches the reference, CBV mode applies and the battery voltage is limited. At this time, the charging current of the battery begins to decrease and so does the output current of the fuel cell. Consequently, the voltage of the fuel cell increases a little. When the load needs peak power within this cycle, CFCC mode applies again. The state-of-charge of the battery, as shown in Fig. 8, increases when the battery is charged and decreases when discharged. During each cycle, the net increase of the state-of-charge is positive. This is because the average power of the load is less than the average output power of the fuel cell and thus the net input power to the battery is positive

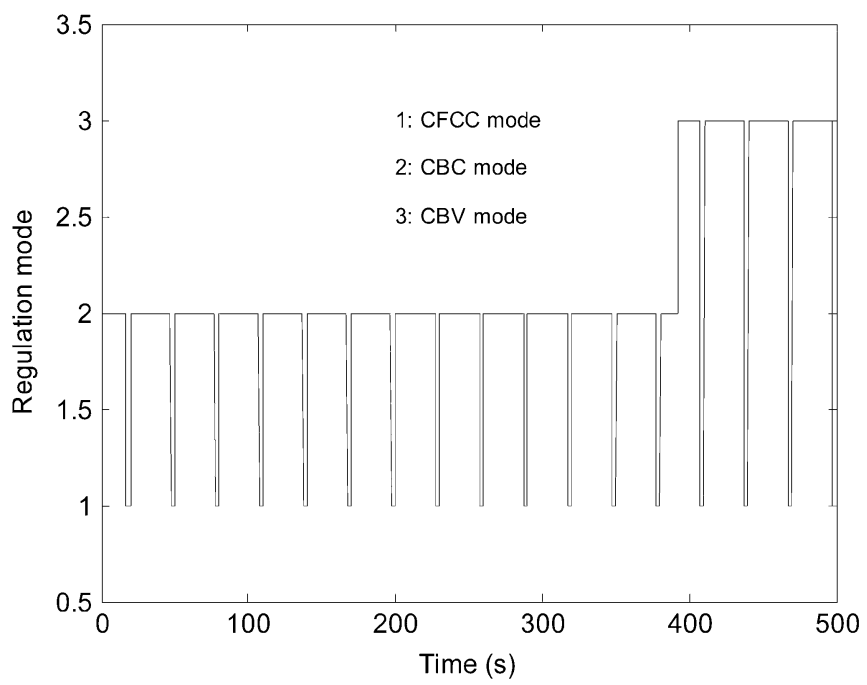

Fig. 9. Change of the regulation mode (1: $\mathrm{CFCC}, 2$ : $\mathrm{CBC}, 3$ : $\mathrm{CBV})$.

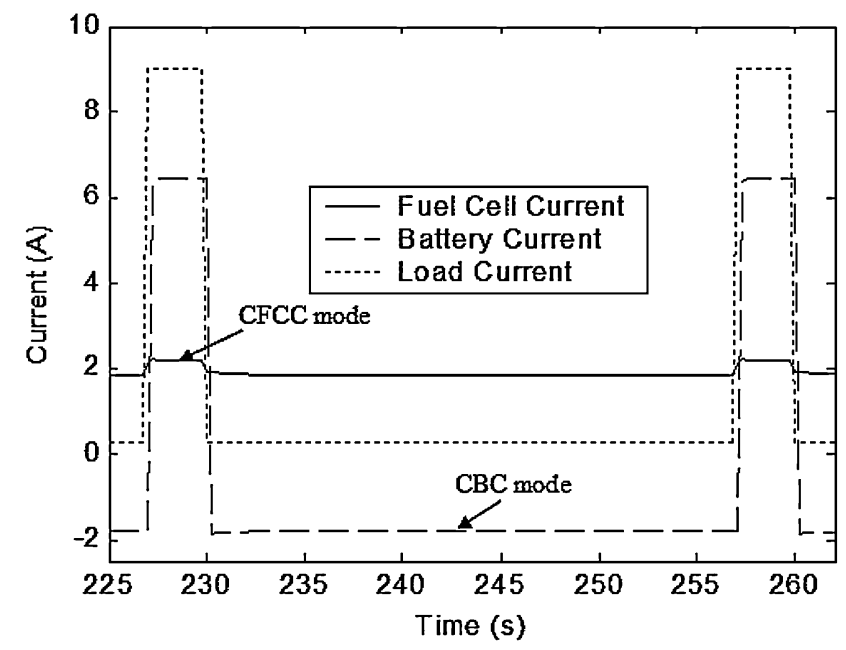

Fig. 10. Zoomed version of the currents of the fuel cell, the battery, and the load.

TABLE II

Gains for CurRent and Voltage ReQulations in the Simulation

\begin{tabular}{c|c|c|c|c|c}
\hline$k_{\text {pifc }}$ & $k_{\text {iife }}$ & $k_{p i}$ & $k_{i i}$ & $k_{p v}$ & $k_{i v}$ \\
\hline $0.02 \mathrm{~A} / \mathrm{A}$ & $2.0 \mathrm{xe}^{-6} \mathrm{~A} /(\mathrm{A} . \mathrm{s})$ & $0.02 \mathrm{~A} / \mathrm{A}$ & $2.0 \mathrm{xe}^{-6} \mathrm{~A} /(\mathrm{A} . \mathrm{s})$ & $0.01 \mathrm{~V} / \mathrm{V}$ & $1.0 \mathrm{xe}^{-6} \mathrm{~V} /(\mathrm{V} . \mathrm{s})$ \\
\hline
\end{tabular}

during each cycle. If the load continued to draw the current as given, the state-of-charge of the battery would eventually reach unity and then cycle between unity and some fraction. Fig. 9 shows the regulation mode is selected correctly according to the battery charge level and the load characteristics. Simulation results show that the fuel cell current, battery current and battery voltage are regulated properly and the power of the active hybrid is reasonably shared between the two sources. Simulation results also suggest that the power converter can be regulated to meet the multiple objectives required by hybrid power sources.

\section{EXPERIMENTAL VALIDATION}

The control strategy described previously was validated on real hardware. A prototype of the active hybrid power source was built using an H-Power D35 PEM fuel cell stack and a 


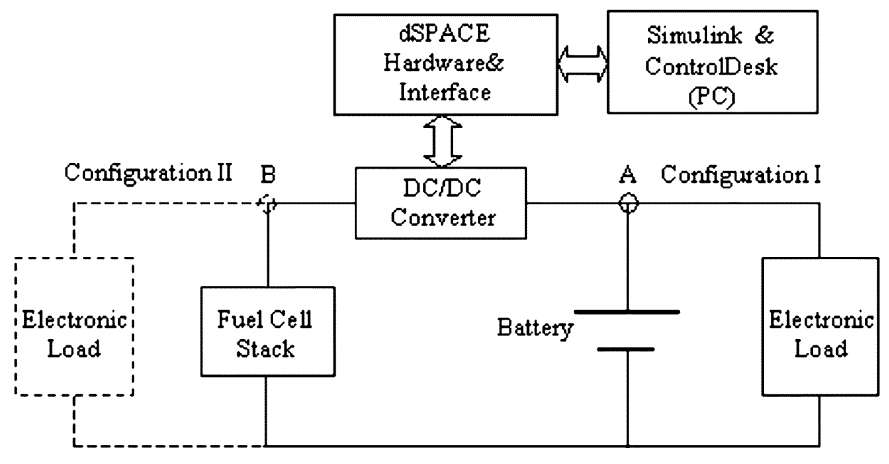

Fig. 11. Block diagram of the experiment environment.

number of Sony 18650 lithium-ion cells. Fig. 11 shows the block diagram of the experiment environment, which consisted mainly of a fuel cell stack and a battery as well as a bi-directional dc/dc converter that was positioned between them. The switching frequency of the converter was $50 \mathrm{kHz}$. The hybrid power source had two output terminals (A and B) with different terminal voltages. Connecting the load to the battery at node $\mathrm{A}$ or to the fuel cell at node B produced the two different configurations (I and II, respectively). The power converter was controlled by a real-time dSPACE controller board (model DS1103 PPC). The currents and voltages of both electrochemical components were monitored and fed into the controller. The controller calculated the duty cycle of the power converter and sent out the commands to the hardware.

The fuel cell stack had a nominal power capacity of $35 \mathrm{~W}$ and a nominal open-circuit voltage of $24 \mathrm{~V}$. The terminal voltage of the stack was about $18 \mathrm{~V}$ when fully loaded. Eight lithium-ion cells were used, four cells in series and two such strings in parallel; thus the nominal open-circuit voltage of the battery was 14.4 V. The nominal capacity of each cell was $1.4 \mathrm{Ah}$. With such a battery configuration, the power converter could work in an appropriate duty cycle range, where the converter could achieve a good efficiency, and the battery could provide sufficient current (two times the maximum safe discharging current of one cell) to support the peak power demand of the load. The electronic load drew a pulse current with a period of $30 \mathrm{~s}$. For Configuration I, the low current was $0.3 \mathrm{~A}$ for $27 \mathrm{~s}$ and the high current was $9 \mathrm{~A}$. For Configuration II, the low current was also $0.3 \mathrm{~A}$ for $27 \mathrm{~s}$ but the high current was $8 \mathrm{~A}$ for $3 \mathrm{~s}$ because in this case (for the same load power demand) the output voltage (equal to the voltage of the fuel cell stack) was higher than that in Configuration I (equal to the voltage of the battery). This cycle was intentionally chosen for the purpose of investigating the performances of the control strategy, but of course in a practical application, the power of the load might vary more randomly and not so regularly. Another reason for choosing such a cycle was that, as mentioned before, many applications have a common characteristic of a relatively low average power need but a very high pulse power demand in short duration in the load profile. Table III describes the major components used. Fig. 12 shows the photograph of the experiment environment.

Tests were conducted on the experiment platform described previously with the two configurations (I and II) to validate the system control and to demonstrate the flexibility and generality

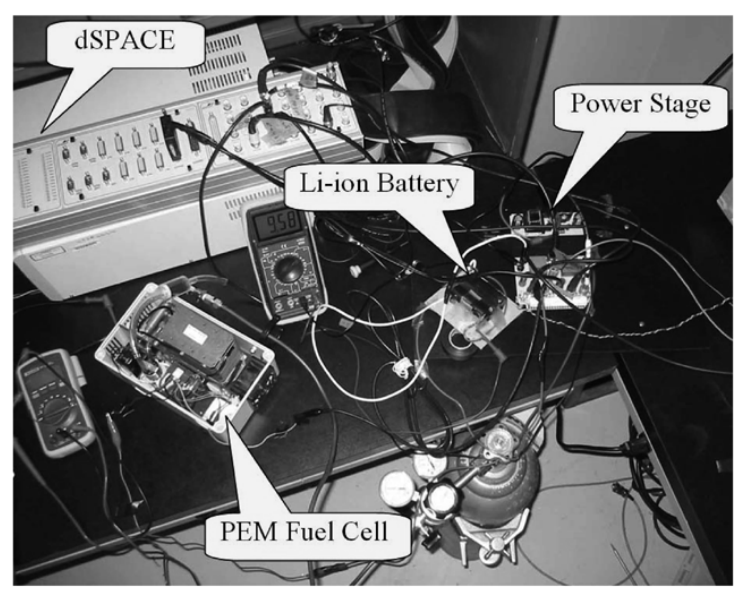

Fig. 12. Photograph of the experiment environment.

TABLE III

COMPONENTS USED IN THE HYBRID POWER SOURCE

\begin{tabular}{c|c|c}
\hline Component & Description & Comments \\
\hline $\begin{array}{c}\text { PEM Fuel Cell } \\
\text { Stack }\end{array}$ & H Power DS35 & $\begin{array}{c}25 \text { cells in series, } 2.9 \mathrm{~kg} \text { including all of the } \\
\text { peripherals, } 5092 \mathrm{~cm}^{3}\end{array}$ \\
\hline $\begin{array}{c}\text { Li-Ion Battery } \\
\text { Pack }\end{array}$ & SonyUS18650 & $\begin{array}{c}4 \times 2 \text { cells (series by parallel connections) } 1.4 \mathrm{Ah}, 42 \\
\mathrm{~g} / \mathrm{cell}, 16.6 \mathrm{~cm}^{3} / \mathrm{cell}\end{array}$ \\
\hline Load & Chroma 6310 & Digitally controllable \\
\hline DC/DC Converter & Synchronous Buck Converter & About $30 \mathrm{~cm}^{3}, 30 \mathrm{~g}$, greater than $92 \%$ efficiency \\
\hline Controller & dSPACE DS1103 Controller Board & Controller hardware plus interface \\
\hline
\end{tabular}

of the control strategy. The control algorithm that was developed in Simulink was compiled and downloaded to the dSPACE controller board to control the real hardware. The limit of the fuel cell current was set at $2.2 \mathrm{~A}$, which was the safe average current from the fuel cell although the instantaneous current could be a little larger but at a risk of overheating the membrane. The reference charging current of the battery was set to $1.8 \mathrm{~A}$, according to the maximum safe charging rate of the battery. The voltage limit of the battery was set to $16.4 \mathrm{~V}(4.1 \mathrm{~V}$ for each cell) to avoid over-charging. The maximum discharging current of the battery was set to $8 \mathrm{~A}$, according to the maximum safe discharging rate of the battery. The same control algorithm was used in both configurations. Gains for current and voltage regulations in the controller are the same as for simulation. Experiment results are shown in Figs. 13-20.

Figs. 13 and 14, respectively, show the currents and voltages of the fuel cell and the battery in Configuration I. Finer details of these current and voltages are shown in Figs. 15 and 16. Fig. 13 shows that initially the currents of the fuel cell and the battery varied periodically since they were regulated alternately. It is seen that when the load drew low power the fuel cell stack provided about 1.7 A current, supplying 0.3 A current to the load and at the same time charging the battery at 1.8 A current (reaching the maximum safe charging current). In this case, the charging current of the battery was regulated (CBC mode applied), and the fuel cell current was less than the limit and its value was dependent on the load. It is shown in Fig. 14 that the battery voltage increased gradually during the 


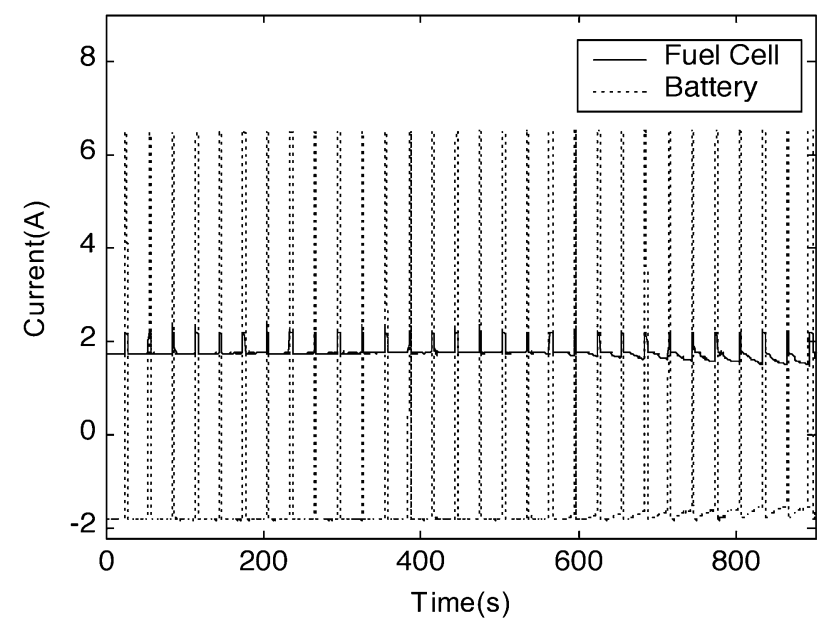

Fig. 13. Currents from the fuel cell and the battery in Configuration I.

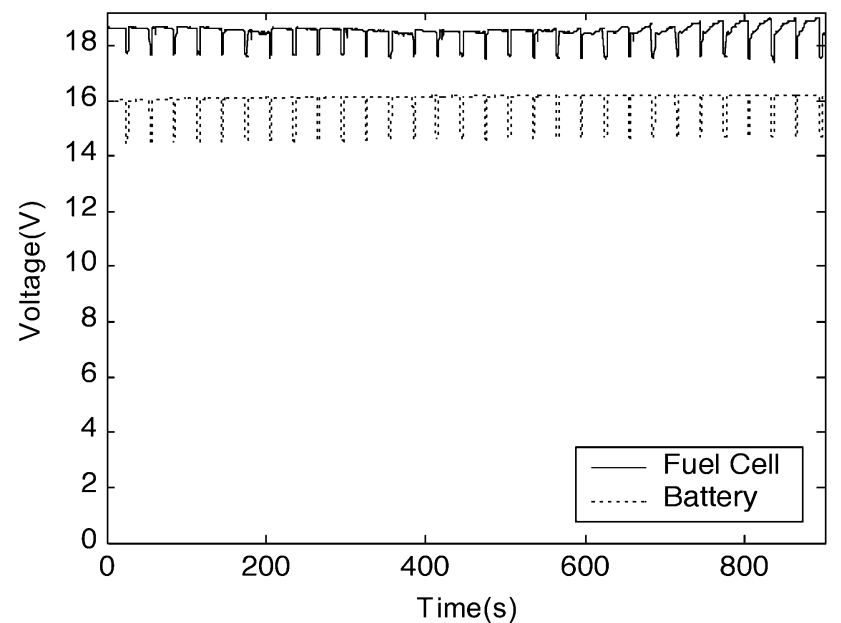

Fig. 14. Voltages of the fuel cell and the battery in Configuration I (Top: fuel cell voltage. Bottom: battery voltage).

low power period. When the load drew peak power, both the fuel cell and the battery supplied power to the load and the fuel cell provided 2.2 A current (reaching the current limit). In this case, the fuel cell current was regulated (CFCC mode applied) and the discharging current of the battery depended on the load. At this moment, the battery discharged at approximately $6.5 \mathrm{~A}$ current, and the voltage dropped suddenly to about $14.7 \mathrm{~V}$ and then decreased gradually. An important observation from Fig. 14 is that over many cycles the battery voltage increased. This was due to the fact that the average power demand of the load was less than the average output power of the fuel cell stack. During any one cycle, the net power transferred to the battery was positive, which caused the battery voltage to increase slightly by the end of each cycle. Fig. 14 also shows that over many cycles the fuel cell voltage decreased. This was because the fuel cell needed to provide more power to charge the battery as the battery voltage increased (since the charging current was constant, as the battery voltage increased, so did the charging power).

After around $600 \mathrm{~s}$, when the battery voltage reached the voltage limit $(16.4 \mathrm{~V}), \mathrm{CBV}$ mode applied and the battery voltage was regulated (see Fig. 16). At this mode, the charging current tapered and the fuel cell current decreased accordingly when the load was low, as shown in Fig. 15. As a result, the fuel cell voltage increased a little (see Fig. 16) because less power

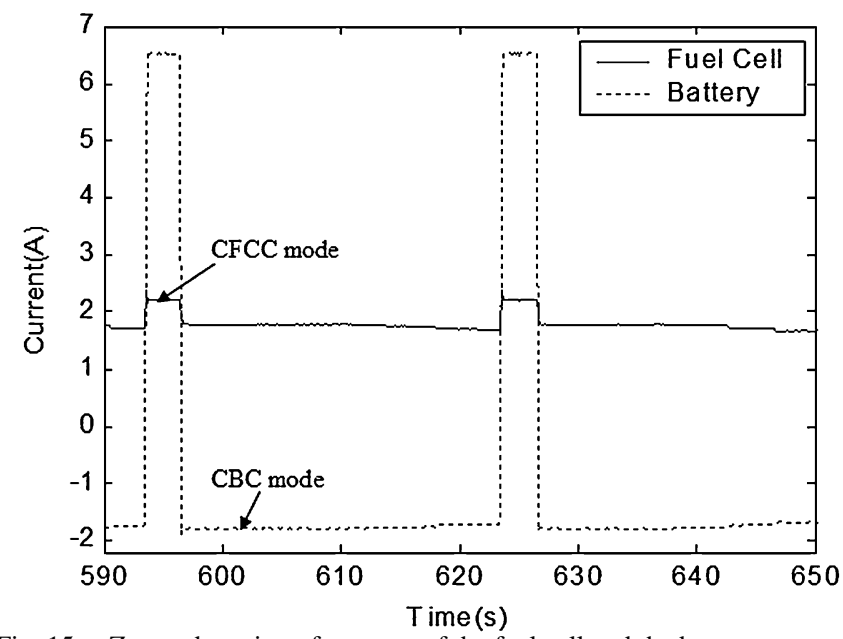

Fig. 15. Zoomed version of currents of the fuel cell and the battery.

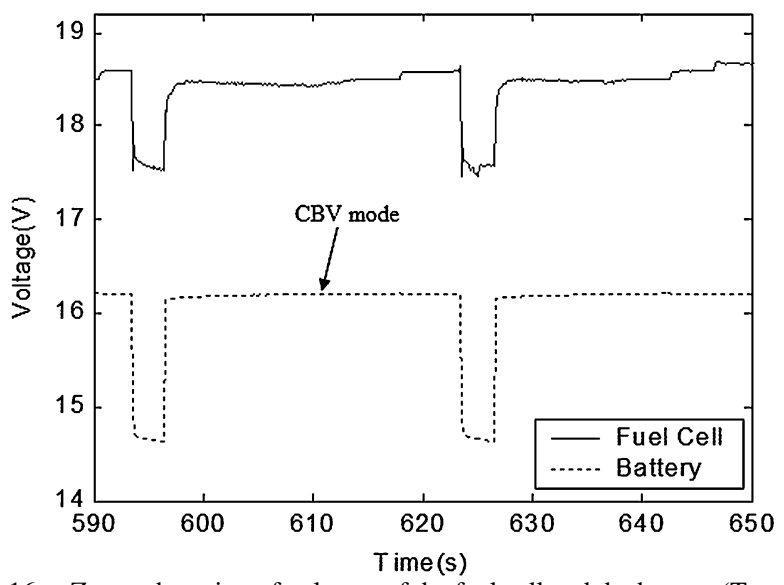

Fig. 16. Zoomed version of voltages of the fuel cell and the battery (Top: fuel cell voltage. Bottom: battery voltage).

was used to charge the battery. When the load demanded higher power, CFCC mode applied again. Later on, the regulation mode changed in the following order: from CFCC, to CBC, $\mathrm{CBV}$, and back to CFCC. It is seen that the regulation mode was selected correctly and the fuel cell current, battery current and battery voltage were regulated properly. If the load had drawn this current continuously, the voltage of the battery would have cycled between the reference voltage and a lower voltage.

The currents and voltages of the fuel cell and the battery in Configuration II are, respectively, shown in Figs. 17 and 18. Figs. 19 and 20 show the finer details of these current and voltages. Fig. 17 shows that initially the currents of the fuel cell and the battery varied periodically since they were regulated alternately. It is seen that when the load drew low power the fuel cell stack provided about $1.8 \mathrm{~A}$ current, supplying $0.3 \mathrm{~A}$ current to the load and charging the battery at $1.8 \mathrm{~A}$ current at the same time. The current of the fuel cell was a little larger than that in Configuration I. This was because, in Configuration II, the voltage of the load (equal to the fuel cell voltage) was greater than that in the previous case (equal to the battery voltage) and the load drew more power. It is shown that the battery voltage increased gradually during the low power period. In this case, the charging current of the battery was regulated (CBC mode applied), and the fuel cell current was less than the reference value and its value was dependent on the load. When the load drew 


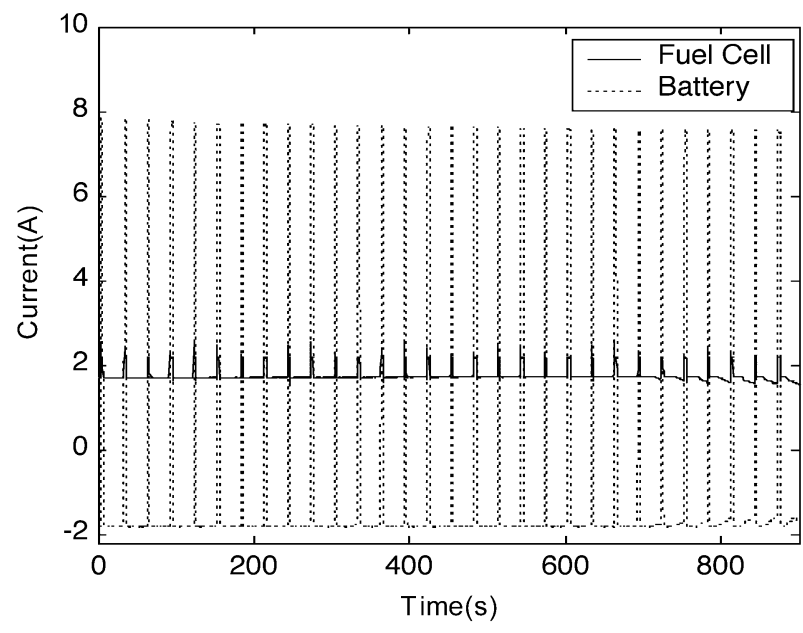

Fig. 17. Currents from the fuel cell and the battery in Configuration II.

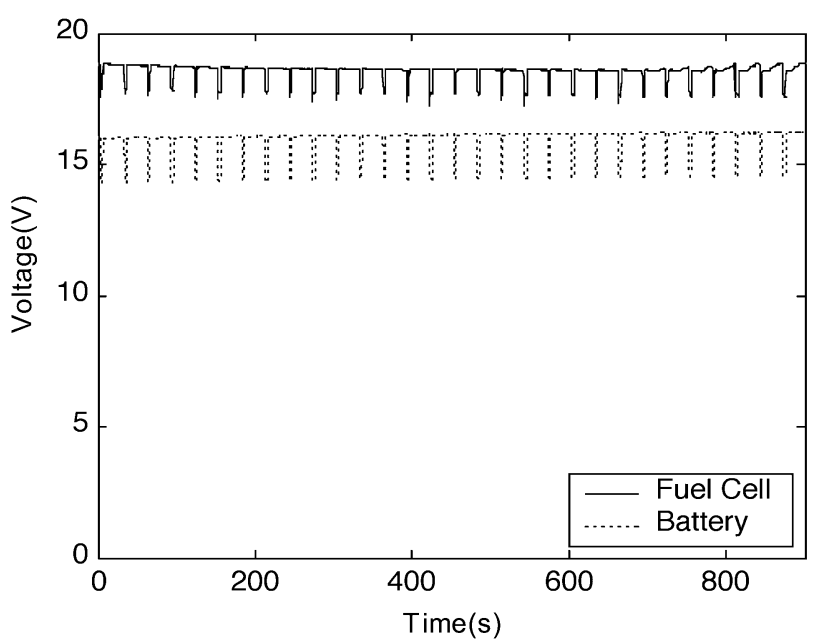

Fig. 18. Voltages of the fuel cell and the battery in Configuration II (Top: fuel cell voltage. Bottom: battery voltage).

peak power, the fuel cell supplied $2.2 \mathrm{~A}$ current. In this case, the fuel cell current was regulated (CFCC mode applied) and the discharging current of the battery depended on the load. At this time, the battery discharged at approximately 7.6 A current, and the voltage dropped suddenly and then decreased gradually. Fig. 18 also suggests that over many cycles the battery voltage increased and the fuel cell voltage decreased.

After around $770 \mathrm{~s}$, when the battery voltage reached the voltage limit, the battery voltage was regulated, i.e., CBV mode applied (see Fig. 20). At this mode, the charging current, and accordingly, the fuel cell current decreased (see Fig. 19), and as a result, the fuel cell voltage increased a little, as shown in Fig. 20. When the load became high, CFCC mode applied again. Later on, the regulation mode changed in the following order: from CFCC, to CBC, CBV, and back to CFCC. It is seen that the regulation mode was also selected correctly in Configuration II.

Experiment results show that the active power in the two configurations of active hybrids is reasonably shared between two sources with the multiobjective control strategy. It is found from the experiment results that the efficiency of the hybrid power source is higher than $92 \%$, which makes the hybrid power source really attractive. Experiment results validate that

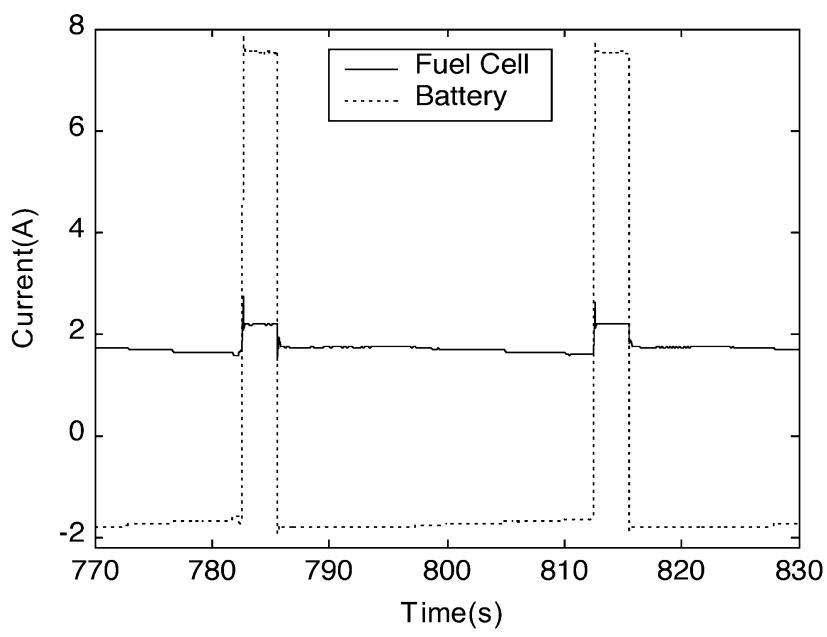

Fig. 19. Zoomed version of currents of the fuel cell and the battery.

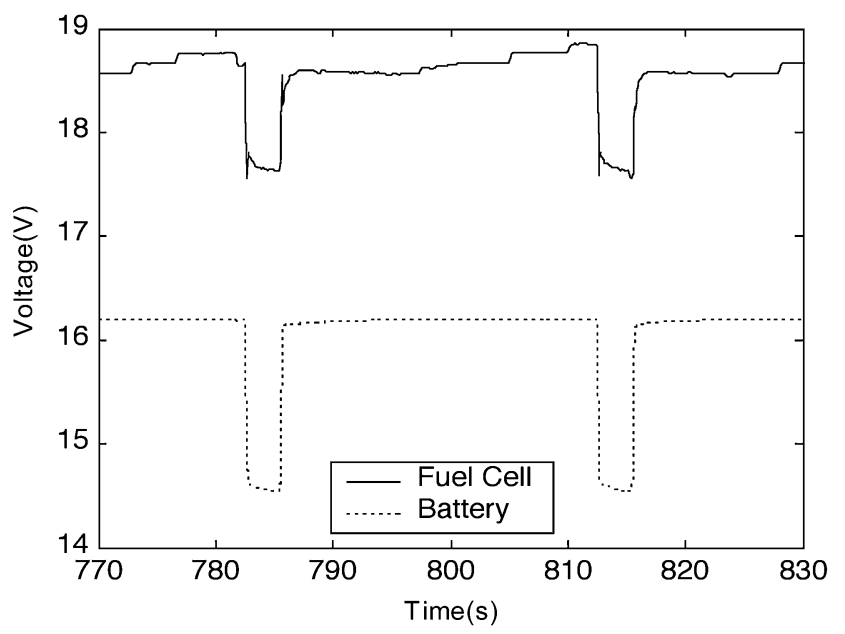

Fig. 20. Zoomed version of voltages of the fuel cell and the battery (Top: fuel cell voltage. Bottom: battery voltage).

the same control strategy is applicable to different configurations and has great flexibility and generality. A significant observation was that the fuel cell current had a slightly larger overshoot in Configuration II than in Configuration I when the load drew peak power. This was because in Configuration II the fuel cell was closer to the load and it took time for the inductor in the power converter to reverse the current when the battery was discharged. But this time delay was very short (in millisecond), and it did not affect the pulsed operation of the power source (in seconds) significantly. Experiment results also validate that the power converter can be properly regulated to meet the multiple objectives required by hybrid power sources.

It is shown in Fig. 14 that when the load drew peak current the power source sustained a voltage between 14 and 15 $\mathrm{V}$ at the output terminal in Configuration I. The load drew from the hybrid power source about $130.5 \mathrm{~W}(14.5 \mathrm{~V} \times 9 \mathrm{~A})$ power (shared by the fuel cell and the battery), which was much greater than the maximum power available from the fuel cell stack. It is seen from Fig. 18 that the terminal voltage of the power source varied between 17 and $18 \mathrm{~V}$ in Configuration II when the load drew peak current. The hybrid power source provided to the load about $140 \mathrm{~W}(17.5 \mathrm{~V} \times 8 \mathrm{~A})$ power, which was four times as much as the maximum power available from the fuel cell 
stack. It is clear that the hybrid power source increased the peak power capacity dramatically with the addition of a power converter and appropriate controls although increasing the system weight by a small percentage (about 10\%). However, the increase in the system weight would be much lower than that in the passive hybrid to meet the same peak power requirement. Note that the volume of hybrid power sources is the same as the fuel cell alone since the original fuel cell case had enough unused space to accommodate the battery and the power converter. It is clear that the active hybrid system with the addition of appropriate power electronics and controls is superior to the standalone component and the passive hybrid in terms of specific power and power density.

\section{CONCLUSION}

Hybrid power sources composed of fuel cells and secondary batteries combine the high energy density of fuel cells with the high power density of batteries. A bi-directional dc/dc power converter that is placed between the fuel cell and the battery can regulate and balance the power flow between them. This paper presents a novel, flexible strategy for multiobjective control of the power converter in the active hybrid fuel cell/battery power source. The control strategy can be used for two different configurations without any change. The control strategy is implemented in Simulink and then tested through simulation and experiments.

Simulation and experiment results show that the multiobjective control strategy is able to select the regulation mode correctly, and the fuel cell current, battery current and battery voltage are regulated appropriately. Experiment results validate that the multiobjective control strategy has great flexibility and generality and the power converter can be regulated to meet the multiple objectives required by hybrid power sources. The proposed state machine model of multiobjective control strategy can be used in other kinds of hybrid power sources. It is clear from this study that the hybrid power source increases the peak power capacity greatly (four times the maximum power available from the fuel cell stack) with the addition of a power converter and appropriate controls.

\section{REFERENCES}

[1] T. B. Atwater, P. J. Cygan, and F. C. Leung, "Man portable power needs of the 21st century: I. Applications for the dismounted soldier. II. Enhanced capabilities through the use of hybrid power sources," J. Power Sources, vol. 91, no. 1, pp. 27-36, Nov. 2000.

[2] R. F. Nelson, "Power requirements for batteries in hybrid electric vehicles," J. Power Sources, vol. 91, no. 1, pp. 2-26, Nov. 2000.

[3] L. P. Jarvis, T. B. Atwater, and P. J. Cygan, "Hybrid power sources for land warrior scenario," IEEE Aerosp. Electron. Syst. Mag., vol. 15, no. 9, pp. 37-41, Sep. 2000.

[4] L. P. Jarvis, P. J. Cygan, and M. P. Roberts, "Hybrid power source for manportable applications," IEEE Aerosp. Electron. Syst. Mag., vol. 18, no. 1, pp. 13-16, Jan. 2003.

[5] M. Nadal and F. Barbir, "Development of a hybrid fuel cell/battery powered electric vehicle," Int. J. Hydrogen Energy, vol. 21, no. 6, pp. 497-505, Jun. 1996.

[6] P. B. Jones, J. B. Lakeman, G. O. Mepsted, and J. M. Moore, "A hybrid power source for pulse power applications," J. Power Sources, vol. 80, no. $1-2$, pp. 242-247, Jul. 1999.
[7] Z. Jiang, L. Gao, and R. A. Dougal, "Design and experimental tests of control strategies for active hybrid fuel cell/battery power sources," $J$. Power Sources, vol. 130, no. 1, pp. 163-171, May 2004.

[8] P. Stewart, G. W. Jewell, R. E. Clark, and P. J. Fleming, "Controllability analysis of multi objective control systems," in Proc. IEEE Int. Symp. Computer-Aided Control System Design, vol. 1, Sep. 2002, pp. 74-79.

[9] M. Trentini and J. K. Pieper, "A case study of multi-objective control: Synthesis and analysis," in Proc. IEEE Int. Conf. Control Applications, vol. 2, Sep. 1998, pp. 1001-1005.

[10] O. Djekic, M. Brkovic, and A. Roy, "High frequency synchronous buck converter for low voltage applications," in Proc. IEEE 29th Annu. Power Electronics Specialists Conf., vol. 2, May 1998, pp. 1248-1254.

[11] D. Drechsel, "An adaptive control system modeled as finite state machine," in Proc. IEEE Annu. Convention Exhibition in India, Jan. 1990, pp. 124-128.

[12] T. Lovett, A. Monti, E. Santi, and R. Dougal, "A multilanguage environment for interactive simulation and development of controls for power electronics," in Proc. IEEE 32nd Annu. Power Electronics Specialists Conf., vol. 3, 2001, pp. 1725-1729.

[13] V. Donescu, M. Dawande, Z. Yao, and V. Rajagopalan, "dSPACE based controller for active power filters," in Proc. 23rd Int. Conf. Industrial Electronics, Control Instrumentation, vol. 2, 1997, pp. 810-815.

[14] Z. Jiang, S. Liu, and R. Dougal, "Design and testing of spacecraft power systems using VTB," IEEE Trans. Aerosp. Electron. Syst., vol. 39, no. 3, pp. 976-989, Jul. 2003.

[15] Z. Jiang and R. Dougal, "Design and testing of a fuel-cell-powered battery-charging station," J. Power Sources, vol. 115, no. 2, pp. 279-287, Apr. 2003.

[16] Z. Jiang, R. Dougal, S. Liu, S. Gadra, A. Ebner, and J. Ritter, Simulation of thermally-coupled metal-hydride hydrogen storage and fuel cell systems, in J. Power Sources, to be published.

[17] L. Gao, S. Liu, and R. Dougal, "Dynamic lithium-ion battery model for system simulation," IEEE Trans. Compon. Packag., vol. 25, no. 3, pp. 495-505, Sep. 2002.

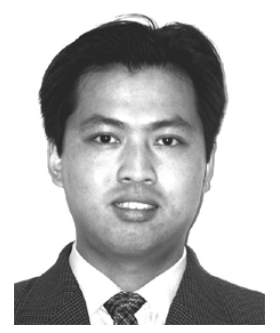

Zhenhua Jiang (M'03) received the B.Sc. and M.Sc. degrees in electrical engineering from Huazhong University of Science and Technology, Wuhan, China, in 1997 and 2000, respectively, and the Ph.D. degree in electrical engineering from the University of South Carolina, Columbia, in 2003.

$\mathrm{He}$ is currently a Postdoctoral Fellow at the University of South Carolina. His research interests include digital controls for power electronics, renewable power systems such as photovoltaic, fuel cell and battery systems, hybrid advanced power sources, and modeling and simulation of interdisciplinary systems.

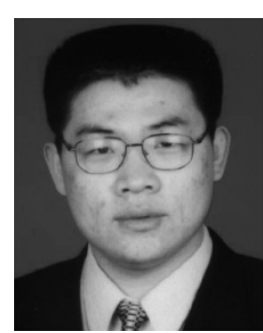

Lijun Gao (M’04) received the Ph.D. degree in electrical engineering from the University of South Carolina, Columbia, in 2003.

His current research interests include design and control of advance hybrid power sources and systems, modeling and simulation of hybrid electric vehicles (HEVs), artificial intellgience based applications in electrochemical energy components, and advanced motor control.

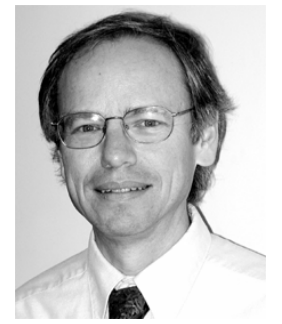

Roger A. Dougal (S'74-M'78-SM'94) received the $\mathrm{Ph} . \mathrm{D}$. degree in electrical engineering from Texas Tech. University, Lubbock, in 1983.

He then joined the faculty at the University of South Carolina, Columbia. He is the Director of the Virtual Test Bed Project, which is developing an advanced simulation and virtual prototyping environment for multidisciplinary dynamic systems.

Dr. Dougal received the Samuel Litman Distinguished Professor of Engineering Award. 